Article

\title{
Parental Background and Union Formation Behavior of Native Born Individuals in Sweden with a Foreign Background
}

\author{
Aycan Çelikaksoy
}

Swedish Institute for Social Research (SOFI), Stockholm University Linnaeus Center for Integration Studies (SULCIS), 10691 Stockholm, Sweden; E-Mail: aycan.celikaksoy@sofi.su.se

Received: 24 February 2014; in revised form: 3 June 2014 / Accepted: 13 June 2014 /

Published: 27 June 2014

\begin{abstract}
Social cohesion in destination countries is an increasingly important issue due to the multiethnic structures in these countries and due to ongoing international migration. Union formation of individuals across different backgrounds can be seen as an indicator of social cohesion. However, this phenomenon is important not only in the case of first generation migrants but also for their descendants. Thus, this paper analyzes the determinants of intergroup union formation patterns of the native born individuals with a foreign background focusing on the role of parental background in addition to individual as well as marriage market characteristics. High quality data at the individual level, from Statistics Sweden, for the whole population of interest is utilized. The results indicate that parental composition is an important determinant of union formation behavior. Furthermore, there are gender specific pathways of the parental background effects.
\end{abstract}

Keywords: intermarriage; intergroup union; descendants; native born; parental background; social cohesion

\section{Introduction}

How individuals sort into household units has been widely studied in various disciplines due to its implications regarding various individual outcomes such as fertility, employment, income but also due to its implications regarding the development of social and economic inequality across groups over time and across generations. As documented and theorized in the literature in social sciences as well as biology, partnership formation is more likely to take place among similar individual characteristics, so called positive assortative mating, on characteristics such as education, income, socioeconomic background, ethnicity, religion and religiosity as well as height, weight, IQ, and social class [1-4]. 
Consistent with this literature, the tendency of immigrants to marry within their group is a common finding [5,6]. However, explanations across disciplines vary regarding why individuals mate assortatively. Explanations in the economics discipline focused on the efficiency gains arguing that similarity in certain partner characteristics simplifies, for example, joint decision making and rearing of children [7]. However, ongoing international migration and increasing ethnic diversity in destination countries raises several questions regarding intermarriages, where factors such as opportunity of contact, segregation as well as opinions of different groups, including the majority group, towards intermarriages are also becoming very important. Thus, how individuals of different ethnic origin sort into household units in a multicultural society can be seen as an indicator of the strength and persistence of social, economic and structural boundaries across ethnic groups.

Intermarriage in relation to migration has mainly been the focus of studies from a perspective of integration. In his commonly cited work Gordon (1964) has argued that intermarriage could be seen as a measure of the final stage of assimilation in a destination country, where social cohesion between immigrants and natives is achieved at the most intimate level. Indeed, several studies argue that intermarriage is positively associated with social and economic integration of immigrants [8-10]. It might serve as a catalyst in the integration process of immigrants, while there might also be selection into this behavior since relatively more integrated immigrants might be more likely to intermarry $[11,12]$. This measure can also be used as an indication of the openness and the degree of acceptance of the native population towards immigrants. Studies in this line of literature mainly focus on immigrantnative marriages. From a perspective of social cohesion in multiethnic societies it is also important to analyze the union formation patterns for the native born populations. Several studies have shown that native born individuals are more likely to intermarry when compared to foreign born individuals. However, we know little about the different types of unions of the native born. The lack of studies on this topic is partly due to data limitations, since such an analysis requires information on the country of origin of not only the individuals but also parents, spouses as well as parents in law. Several international studies have to rely on information on citizenship or self-reported ethnic background. One of the very important challenges in relation to this type of data is related to 'ethnic attrition', where for e.g. native born individuals do not self-identify as being from a certain background despite having foreign born parents, thus disappearing from the sample [13-15].

\subsection{Intergroup Unions}

In the case of first generation, however, there is a rich array of literature focusing on intergroup unions, where the main factors that influence intergroup union formation behavior can be listed under the broad categories of individual influences, structural influences as well as influences in relation to norms and values [16-21]. Several studies have shown that individual characteristics, such as education are important determinants of intergroup union formation behavior, where there is a positive relationship between education and intergroup unions. One reason for this is that educational institutions create environments with opportunities to meet individuals from different ethnic groups [2]. In addition, higher educated people tend to live in relatively less ethnically segregated areas [22]. Furthermore, assortative mating patterns are shifting, where unions are more likely to be formed on grounds of attained characteristics such as education rather than ascribed characteristics such as 
ethnicity $[2,23,24]$. Structural influences on the other hand, mainly include factors related to the structure of the marriage market, such as the availability of potential spouses from one's own group measured by sex ratios [25]. Union formation behavior can also be influenced by norms and values of the relevant groups as well as the society at large. In the case of first generation, issues in relation to parents and parental background are usually not included in the analysis since we do not have parental information for adult immigrants.

There are fewer studies in the case of native born individuals with foreign backgrounds when compared to the first generation $[15,17,19,21,22]$. The European studies that focus on intergroup unions for the native born mainly focus on individuals from few countries of origin generally using survey data sets due to lacking information in larger data sets. In these types of studies, intergroup unions are commonly defined as a union formed with any other group that is outside of one's own group. Studies focusing on the union formation patterns of native born individuals also follow the main framework of the general literature on intergroup unions [26-28]. However, parental background can be an important factor influencing union formation patterns of native born individuals. Although, there is a rich array of literature focusing on the influence of parents on their children in terms of a wide range of outcomes such as fertility, divorce, age at marriage as well as religion, etc. there is a lack of studies regarding intergroup unions within this context [29-34]. Furthermore, these studies indicate that parental influence on their children's behavior varies by the gender of the child as well as the parents, while the direction of these gender specific pathways vary by the outcome in question.

Due to an increasing number of native born individuals with a foreign background, an important question is to what extent the social and structural boundaries in relation to intergroup unions survive and influence union formation behavior of the native born. However, it is not straightforward to define intergroup unions for the native born populations due to data construction practices as discussed earlier but also due to the large proportions of native born with mixed parental ethnic backgrounds. Thus, following earlier literature on minority-majority unions, intergroup union is defined as a union between two individuals with and without a migration history. The paper focuses on the union formation behavior of native born individuals in Sweden who have foreign backgrounds and focus on the determinants of forming a union with a native born individual with no foreign background for two generations. The patterns of intergroup unions in relation to foreign backgrounds either at the individual or parental level can shed light on the existence and the degree of boundaries as well as the survival of these boundaries for the next generations. Thus, this paper focuses on the union formation behavior of a relatively invisible group and analyzes the determinants of forming a specific type of intergroup union. Several studies have shown that parental background characteristics such as cultural capital or religiosity as well as union formation and dissolution patterns have an influence on their children's behavior [16,17]. Thus, the influence of the parental background, regarding a native versus a foreign background, on children's union formation behavior might vary in terms of gender of the parent as well as the gender of the child. In this case, the results might also indicate parental preferences or role model related mechanisms. Previous literature points out to the relative importance of the father's background in relation to daughters' union formation behavior for immigrant families [35,36]. However, we do not know whether there are gender specific pathways in the case of native born individuals. Thus, we focus on two main questions in relation to whether the parental 
composition plays a role in intergroup union formation patterns and whether there is a gender specific pathway in terms of this relationship.

\subsection{Immigration to Sweden}

Sweden has a relatively large immigrant population. Approximately 15 percent of the working age population residing in Sweden is foreign born. In addition, another 12 percent of the population is born in Sweden with at least one foreign-born parent. There have been three main sources of immigration to Sweden. The first concerns migration from the other Nordic countries, primarily Finland, due to the common Nordic labor market established in 1954. The second concerns labor migrants from Southern and Eastern European countries in the 1950s and 1960s recruited to work in the, at the time, booming manufacturing sector. The third concerns refugee migration. After the late-1960s, labor migration became more restrictive and refugee migration as well as family (re)unification became the largest sources of migration to Sweden. Refugee migration to Sweden stemmed from Estonia in 1944, Hungary in the late 1950s, Czechoslovakia and Poland in the late 1960s, Latin America, the Middle East and Africa in the 1970s, Yugoslavia (mainly Bosnia-Herzegovina) in the 1990s and Iraq in the early 2000s. In 2005, the five largest immigrant groups in Sweden originated from Finland, Iraq, Yugoslavia, Iran and Bosnia-Herzegovina.

Sweden is a unique and interesting country to study within the scope of this paper. Sweden was one of the very few EU countries to immediately open its doors to citizens from the EU accession countries of 2004, 2007 as well as 2013 in addition to taking in many refugees simultaneously. In addition, today, Sweden is one of the most open labor migration systems in the world. Thus, social cohesion measures are one of the important indicators in terms of how successful a destination country is regarding embracing the multi-ethnicity in the society.

\section{Data and Analytic Strategy}

\subsection{Data}

The data used in the analyses stems from register information at Statistics Sweden (SCB) on the entire working age population (16-65 years of age) residing in Sweden in 2005. Included in the data is detailed individual information on personal, demographic, and labor market characteristics. In addition, information is available on country of birth and education of the mother. Due to partner identification numbers, it is possible to link all individuals with their partners. Partnership is defined as marriage or cohabitation. Information on cohabitation is available only for those with joint children.

The original sample of native born individuals aged 16-65 with at least one foreign born parent is around 500,000. The sample is restricted to individuals aged 18-45, which gives us a sample of around 380,000. Furthermore, the sample is restricted to individuals in a partnership and with non-missing information on country of birth of partners and parents in law. Individuals with missing information on partner's or partner's parents' birth place are dropped from estimation, since this information is necessary to define union type which is the main focus of the paper. Due to this restriction 2 percent of the sample is dropped. After all the restrictions we have a final sample of 137,061 individuals residing in Sweden in 2005. 


\subsection{Analytic Strategy}

Descendants can have a spouse with or without a migration background. The migration background of the spouse can be due to own or parental background. High proportions of unions for the native born where both individuals have a migration background could indicate the existence of boundaries in the marriage market even for the native born populations. Thus, the dependent variable is a dichotomous variable equal to one if the spouse as well as both of the parents of the spouse are born in Sweden, and zero otherwise. Such a union type will be referred to as an "intergroup union" for native born individuals, where the defining category of in-group unions in this case is whether the spouse has a migration background or not. The probability of union formation with a native spouse without a migration background is estimated with linear probability models controlling for parental, individual and marriage market characteristics as well as controlling for cohort and municipality effects.

The individuals in the sample can have three types of parental composition, namely, native born mother and foreign born father; foreign born mother and native born father; and two foreign born parents. To account for marriage market characteristics within Sweden a sex ratio variable is utilized, where it is defined as the proportion female to male within each country of origin in the estimation on men, and vice versa, the proportion male to female within each country of origin, in estimations on women. This variable is used to measure the role of availability of spouses from the opposite sex from each country of origin. Since the individuals are born in Sweden this variable is computed based on the country of birth of the foreign born parent. In cases, where both parents are foreign born and they are not from the same country of origin then mother's country of birth is used for the construction of the variable. The education variables show the completed level of schooling and post schooling. The variable 'married' shows whether the individual is married or in a cohabitation relationship. The variable 'municipality' introduces dichotomous variables for each municipality of residence to account for municipality specific effects that can influence union formation behavior. There are 290 municipalities in Sweden.

The aim of the analyses is to shed light on the factors influencing the probability of intergroup unions for native born individuals with a foreign background in Sweden and to explore whether parental composition has an influence on the likelihood of these unions even after introducing a large set of controls. Furthermore, this paper also addresses whether this relationship varies with the gender of the parent and the child. Thus, we analyze whether the influence of parental background has a gender specific pathway regarding union formation behavior of descendants. These questions are addressed from a perspective of social cohesion measured by a specific definition of union type.

\section{Results}

Sample means of the main variables are reported in Table 1 by gender. The majority, around 73 percent, has a native born spouse without a migration background, which is the dependent variable in the analysis. Parental composition proportions are quite balanced both within and across gender. On average, females have 0.27 years longer education than males. A relatively higher proportion of females are married compared to males. As it can be seen, on average, the availability of men is slightly higher. We can see that a relatively higher proportion of individuals belong to the oldest 
cohort. The differences between males and females with regard to the proportion of each cohort is partly related to gender differences in union formation behavior as well as gender and cohort specific emigration patterns.

Table 1. Descriptive statistics.

\begin{tabular}{ccc}
\hline & Males & Females \\
\hline Native born spouse without a migration background & 0.73 & 0.72 \\
Native born mother & 0.35 & 0.34 \\
Native born father & 0.34 & 0.34 \\
Both parents foreign born & 0.31 & 0.32 \\
Education & 12.23 & 12.50 \\
Age & 37 & 36 \\
Married & 0.63 & 0.66 \\
Sex ratio & 0.949 & 1.05 \\
$1960-1968$ & 0.53 & 0.47 \\
$1969-1975$ & 0.35 & 0.36 \\
$1976-1987$ & 0.12 & 0.17 \\
\hline
\end{tabular}

The probability of being in an intergroup union is estimated by focusing, in turn, on parental composition, individual characteristics, parental education as well as marriage market, municipality and cohort effects. Results, by gender, are shown in Table 2. Results of estimation controlling only for parental composition are reported in Table 2, columns 1, for males and females respectively. Controls for individual characteristics are added in columns 2. In the last model, marriage market characteristics, maternal education, as well as cohort and municipality controls are included in estimation.

The coefficients of main interest are presented in the first two rows of the Table, where, the parental composition category of native born mother and foreign born father is the reference category. The results indicate that having two foreign born parents are negatively associated with the probability of being in an intergroup union. Native born males and females who have two foreign born parents are less likely to have a native born spouse without a migration background by 16.3 and 19.1 percentage points, respectively. After including individual, marriage market and other parental characteristics as well as municipality and cohort controls, the parental composition coefficients decrease in size to 11.8 and 13.3 percentage points for sons and daughters, respectively. These are relatively small changes which indicate that the association between parental composition and union type is quite robust to adding the commonly used predictors of union types in the regressions. This finding is consistent with the literature with regard to explanations such as ethnic compatibility, ethnic identity as well as discrimination in the marriage market, where having a native born parent increases the likelihood of having a native born spouse [21,31,37]. In addition, it can be seen that having a native born father is not significantly different than having a native born mother in terms of union formation behavior of males; however, this is not the case for females. It is significant for females at the one percent level and increases their intergroup union formation probabilities by 1.1 percentage points. Having a native born father is positively associated with intergroup union probabilities of daughters but not that of sons. This result indicates that there is a gender specific pathway of the influence of parental composition on intergroup union formation behavior of descendants, from fathers to daughters. 
Previous literature points out to the relative importance of the father's background in relation to daughters' union formation behavior for immigrant families [35,36]. Thus, taken together, these results indicate that not only in the case of in-group unions of foreign born individuals but also in the case of intergroup unions for native born individuals, the fathers' background seems to play a relatively more important role in their daughter's union formation behavior. Drawing on these arguments, from a parental involvement perspective, which is commonly utilized in this literature, these results indicate that native born fathers' involvement in their daughters' union formation behavior is not different than that of immigrant fathers'.

Consistent with previous studies, we can see in Table 2 that both own and maternal education is positively associated with the likelihood of having a native spouse. These results show that education is an important determinant for union formation behavior, where higher levels of education increase the likelihood of intergroup unions with individuals without a migration background.

Age has a declining positive effect on the likelihood of intergroup unions. Marriage is negatively associated with the likelihood of forming an intergroup union, which shows that cohabiting couples are more likely to be in such unions. This is a common finding in the literature in relation to intermarriages, which seems to hold in the case of intergroup unions of the native born as well. This implies that there is a positive association between the behaviors of forming relatively less traditional forms of unions, such as cohabitation and intergroup unions. However, it should be noted that the reference category in this case is the couples in a cohabitation relationship with joint children. Thus, cohabiting couples without joint children are not observable in the data set. This could create a potential problem if cohabiting couples without joint children systematically differ from those with joint children in relation to first unions. The sex ratio coefficient is negative and significant as expected in the case of females, which shows that the availability of potential male spouses from the ethnic origin of women decreases the likelihood that they form a union with a spouse with a native background. However this is not the case for males. In addition, birth cohorts are controlled for, where the reference category is the birth cohort 1960-1968, to see whether there is a trend in terms of union formation patterns over the birth cohorts. This can be related to several factors, such as changing norms and values in relation to intergroup union over cohorts. However, there is no indication that younger generations have significantly different union formation behavior in terms of intergroup unions after controlling for other variables. Furthermore, the municipality of residence might influence union formation patterns, thus we control for municipality of residence to take account of the characteristics that vary across municipalities.

These results indicate that even after including a rich set of controls parental origin has an important influence in the union formation behavior of native born individuals. Those with two foreign born parents are less likely to form intergroup unions. This might indicate that social and structural boundaries that influence individuals' union formation patterns not only constrain immigrants but also those who are born in Sweden. Furthermore, daughters who have a native born father are more likely to form intergroup unions when compared to those with a native born mother, which is not the case for sons. This result draws attention to the relative importance of the background of the fathers in their daughters' union formation behavior. 
Table 2. Dependent variable: Nativeborn spouse with a native background.

\begin{tabular}{|c|c|c|c|c|c|c|}
\hline & \multicolumn{3}{|c|}{ Males } & \multicolumn{3}{|c|}{ Females } \\
\hline & (1) & (2) & (3) & (1) & (2) & (3) \\
\hline \multicolumn{7}{|l|}{ Parental background } \\
\hline Native born father & $\begin{array}{l}0.003 \\
(0.004)\end{array}$ & $\begin{array}{l}-0.001 \\
(0.004)\end{array}$ & $\begin{array}{l}0.000 \\
(0.004)\end{array}$ & $\begin{array}{l}0.023 \\
(0.004) * *\end{array}$ & $\begin{array}{l}0.017 \\
(0.004) * *\end{array}$ & $\begin{array}{l}0.011 \\
(0.004) * *\end{array}$ \\
\hline Both parents foreign born & $\begin{array}{l}-0.163 \\
(0.004) * *\end{array}$ & $\begin{array}{l}-0.148 \\
(0.004) * *\end{array}$ & $\begin{array}{l}-0.118 \\
(0.004) * *\end{array}$ & $\begin{array}{l}-0.191 \\
(0.004) * *\end{array}$ & $\begin{array}{l}-0.167 \\
(0.004) * *\end{array}$ & $\begin{array}{l}-0.133 \\
(0.004) * *\end{array}$ \\
\hline \multicolumn{7}{|l|}{ Individual characteristics } \\
\hline High School & & $\begin{array}{l}0.050 \\
(0.006) * *\end{array}$ & $\begin{array}{l}0.042 \\
(0.006) * *\end{array}$ & & $\begin{array}{l}0.053 \\
(0.006) * *\end{array}$ & $\begin{array}{l}0.049 \\
(0.006) * *\end{array}$ \\
\hline Short tertiary education & & $\begin{array}{l}0.054 \\
(0.008) * *\end{array}$ & $\begin{array}{l}0.052 \\
(0.008) * *\end{array}$ & & $\begin{array}{l}0.057 \\
(0.008) * *\end{array}$ & $\begin{array}{l}0.057 \\
(0.008) * *\end{array}$ \\
\hline Long tertiary education & & $\begin{array}{l}0.072 \\
(0.006) * *\end{array}$ & $\begin{array}{l}0.071 \\
(0.006) * *\end{array}$ & & $\begin{array}{l}0.093 \\
(0.006) * *\end{array}$ & $\begin{array}{l}0.092 \\
(0.006) * *\end{array}$ \\
\hline Ph.D. & & $\begin{array}{l}0.025 \\
(0.016)\end{array}$ & $\begin{array}{l}0.031 \\
(0.016)\end{array}$ & & $\begin{array}{l}0.057 \\
(0.021) * *\end{array}$ & $\begin{array}{l}0.075 \\
(0.021) * *\end{array}$ \\
\hline Age & & $\begin{array}{l}0.050 \\
(0.004) * *\end{array}$ & $\begin{array}{l}0.040 \\
(0.005) * *\end{array}$ & & $\begin{array}{l}0.046 \\
(0.003) * *\end{array}$ & $\begin{array}{l}0.034 \\
(0.004) * *\end{array}$ \\
\hline Age squared & & $\begin{array}{l}-0.058 \\
(0.005) * *\end{array}$ & $\begin{array}{l}-0.046 \\
(0.007) * *\end{array}$ & & $\begin{array}{l}-0.050 \\
(0.004) * *\end{array}$ & $\begin{array}{l}-0.035 \\
(0.005) * *\end{array}$ \\
\hline Married & & $\begin{array}{l}-0.097 \\
(0.004) * *\end{array}$ & $\begin{array}{l}-0.090 \\
(0.004) * *\end{array}$ & & $\begin{array}{l}-0.060 \\
(0.003) * *\end{array}$ & $\begin{array}{l}-0.051 \\
(0.003) * *\end{array}$ \\
\hline \multicolumn{7}{|l|}{ Marriage market } \\
\hline Sex ratio & & & $\begin{array}{l}0.424 \\
(0.062) * *\end{array}$ & & & $\begin{array}{l}-0.473 \\
(0.054) * *\end{array}$ \\
\hline
\end{tabular}


Table 2. Cont

\begin{tabular}{|c|c|c|c|c|c|c|}
\hline & \multicolumn{3}{|c|}{ Males } & \multicolumn{3}{|c|}{ Females } \\
\hline & (1) & (2) & (3) & (1) & (2) & (3) \\
\hline \multicolumn{7}{|l|}{ Maternal education } \\
\hline Compulsory 9 years. & & & $\begin{array}{l}0.026 \\
(0.007) * *\end{array}$ & & & $\begin{array}{l}0.031 \\
(0.006) * *\end{array}$ \\
\hline High school ( $\leq 2$ years.) & & & $\begin{array}{l}0.049 \\
(0.005) * *\end{array}$ & & & $\begin{array}{l}0.050 \\
(0.005) * *\end{array}$ \\
\hline High school (3 years.) & & & $\begin{array}{l}0.044 \\
(0.008) * *\end{array}$ & & & $\begin{array}{l}0.057 \\
(0.007) * *\end{array}$ \\
\hline Short tertiary education & & & $\begin{array}{l}0.055 \\
(0.007) * *\end{array}$ & & & $\begin{array}{l}0.052 \\
(0.007) * *\end{array}$ \\
\hline Long tertiary education & & & $\begin{array}{l}0.059 \\
(0.007) * *\end{array}$ & & & $\begin{array}{l}0.053 \\
(0.007) * *\end{array}$ \\
\hline Ph.D. & & & $\begin{array}{l}0.042 \\
(0.029)\end{array}$ & & & $\begin{array}{l}0.040 \\
(0.027)\end{array}$ \\
\hline \multicolumn{7}{|l|}{ Birth cohorts } \\
\hline $1969-1975$ & & & $\begin{array}{l}-0.003 \\
(0.007)\end{array}$ & & & $\begin{array}{l}0.010 \\
(0.006)\end{array}$ \\
\hline 1976-1987 & & & $\begin{array}{l}-0.021 \\
(0.014)\end{array}$ & & & $\begin{array}{l}-0.011 \\
(0.011)\end{array}$ \\
\hline Municipality & & & Yes & & & Yes \\
\hline Constant & $\begin{array}{l}0.779 \\
(0.003) * *\end{array}$ & $\begin{array}{l}-0.245 \\
(0.062) * *\end{array}$ & $\begin{array}{l}-0.480 \\
(0.114) * *\end{array}$ & $\begin{array}{l}0.773 \\
(0.003) * *\end{array}$ & $\begin{array}{l}-0.236 \\
(0.047) * *\end{array}$ & $\begin{array}{l}0.428 \\
(0.090) * *\end{array}$ \\
\hline$N$ & 63,817 & 63,817 & 63,817 & 73,244 & 73,244 & 73,244 \\
\hline
\end{tabular}

Notes: Robust standard errors in parentheses; $* p<0.05$; ** $p<0.01$. 


\section{Conclusions}

To explore social cohesion at the most intimate level for native born individuals, this paper has investigated the determinants of union formation patterns of native born individuals with a foreign background. Analyses are based on detailed individual information for the whole population of interest for those residing in Sweden in 2005. The results show that both own as well as parents' education is positively associated with intergroup union formation probabilities, where the groups are defined by whether the spouse has a migration background or not. Those who are in a cohabitation relationship are also more likely to be in an intergroup union. The results show that after accounting for a rich set of controls regarding marriage market, cohort, municipality as well as parental and individual characteristics, parental composition remains to be a significant determinant of union formation behavior for the native born, which might indicate the existence of social and structural boundaries for this group. These boundaries in the marriage market might be related to unobservable factors such as attitudes towards intergroup unions and discrimination or relatively more observable factors related to opportunities of contact such as segregation at different levels. Furthermore, the results show that the influence of parental background on children's union formation behavior vary by the gender of the parent as well as the gender of the child.

\section{Conflicts of Interest}

The author declares no conflict of interest.

\section{References}

1. Epstein, E.; Guttman, R. Mate selection in man: Evidence, theory and outcome. Soc. Biol. 1984, 31, 243-278.

2. Mare, R.D. Five decades of educational assortative mating. Am. Sociol. Rev. 1991, 56, 15-32.

3. McPherson, M.; Smith-Lovin, L.; Cook, J.M. Birds of a feather: Homophily in social networks. Annu. Rev. Sociol. 2001, 24, 415-444.

4. Pencavel, J. Assortative mating by schooling and the work Behavior of wives and husbands. Am. Econ. Rev. 1998, 88, 326-329.

5. Duncan, B.; Trejo, S.J. Ethnic identification, intermarriage and unmeasured progress by Mexican Americans. In Mexican Immigration; Borjas, G.J., Ed.; University of Chicago Press: Chicago, IL, USA, 2007.

6. Kalmijn, M. Intermarriage and homogamy: Causes, patterns, and trends. Annu. Rev. Sociol. 1998, 24, 395-421.

7. Becker, G.S. A Theory of Marriage: Economics of the Family; University of Chicago Press: Chicago, IL, USA, 1974.

8. Qian, Z.; Blair, S.L.; Ruf, S.D. Asian American interracial and interethnic marriages: Differences by education and nativity. Int. Migrat. Rev. 2001, 35, 557-586.

9. Meng, X.; Gregory, R.R. Intermarriage and the economic assimilation of immigrants. J. Labor Econ. 2005, 23, 135-175. 
10. Meng, X.; Meurs, D. Intermarriage, Language and the Economic Assimilation Process: A Case Study of France; IZA Discussion Paper No. 2461; Institute for the Study of Labor (IZA): Bonn: Germany, 2006.

11. Kantarevic, J. Interethnic Marriages and Economic Assimilation of Immigrants; IZA Discussion Paper No. 1142; Institute for the Study of Labor (IZA): Bonn: Germany, 2004.

12. Furtado, D.; Trejo, S.J. Interethnic Marriages and Their Economic Effects; IZA Discussion Paper No. 6399; Institute for the Study of Labor (IZA): Bonn: Germany, 2012.

13. Trejo, S.J.; Duncan, B. Tracking Intergenerational Progress for Immigrant Groups: The Problem of Ethnic Attrition. Am. Econ. Rev. 2011, 101, 603-608.

14. Trejo, S.J.; Duncan, B. Who Remains Mexican? Selective Ethnic Attrition and the Intergenerational Progress of Mexican Americans. In Latinos and the Economy: Integration and Impact in Schools, Labor Markets, and Beyond; Leal, D.L., Trejo, S.J., Eds.; Springer: New York, NY, USA, 2011; pp. 285-320.

15. Alba, R. Bright vs. blurred boundaries: Second generation assimilation and exclusion in France, Germany, and the United States. Ethnic Racial Stud. 2005, 28, 20-49.

16. Qian, Z.; Lichter, D.T. Changing patterns of interracial marriage in a multiracial society. J. Marriage Fam. 2011, 73, 1065-1084.

17. Furtado, D.; Trejo, S.J. Interethnic Marriages and Their Economic Effects. In International Handbook on the Economics of Migration; Constant, A.F., Zimmerman, K.F., Eds.; Edward Elgar Publishing: Cheltenham, UK, 2014.

18. Lievens, J. Interethnic marriage: Bringing in the context through multilevel modelling. Eur. $J$. Popul. 1998, 14, 117-155.

19. Lichter, D.T.; Qian, Z. Measuring marital assimilation: Intermarriage among natives and immigrants. Soc. Sci. Res. 2001, 30, 289-312.

20. Kalmijn, M.; van Tubergen, F. Ethnic intermarriage in the Netherlands: Confirmations and refutations of accepted insights. Eur. J. Popul. 2006, 22, 371-397.

21. Chiswick, B.R.; Houseworth, C.A. Ethnic intermarriage among immigrants: Human capital and assortative mating. Rev. Econ. Househ. 2008, 9, 149-180.

22. Furtado, D. Human capital and interethnic marriage decisions. Econ. Inq. 2012, 50, 82-93.

23. Kalmijn, M. Shifting boundaries: Trends in religious and educational homogamy. Am. Sociol. Rev. 1993, 56, 786-800.

24. Giddens, A. The Transformation of Intimacy: Sexuality, Love, and Eroticism in Modern Societies; Stanford University Press: Stanford, CA, USA, 1992.

25. Blau, P.M.; Schwartz, E. Crosscutting Social Circles: Testing a Macrostructural Theory of Intergroup Relations; Academic Press: New York, NY, USA, 1984.

26. Huschek, D.; de Valk, H.A.G.; Liefbroer, A.C. Does social embeddedness influence union formation choices among the Turkish and Moroccan second generation in the Netherlands? J. Comp. Fam. Stud. 2011, 42, 787-808.

27. Hartung, A.; Vandezande, V.; Phalet, K.; Swyngedouw, M. Partnership preferences of the Belgian second generation: Who lives with whom? Adv. Life Course Res. 2011, 16, 152-163.

28. Simon, P. France and the unknown second generation: Preliminary results of social mobility. Int. Migrat. Rev. 2003, 37, 1091-1119. 
29. Bisin, A.; Verdier, T. Beyond the Melting Pot: Cultural Transmission, Marriage, and the Evolution of Ethnic and Religious Traits. Q. J. Econ. 2000, 115, 955-988.

30. Bisin, A.; Verdier, T. The Economics of Cultural Transmission and the Dynamics of Preferences. J. Econ. Theor. 2001, 97, 298-319.

31. Celikaksoy, A. Intergenerational Transmission of Interethnic Union Formation Patterns in Sweden. Migr. Lett. 2012, 9, 101-114.

32. Murphy, M.; Knudsen, L.B. The Intergenerational Transmission of Fertility in Contemporary Denmark: The Effects of Number of Siblings (Full and Half), Birth Order, and Whether Male or Female. Popul. Stud. 2002, 56, 235-248.

33. Schönpflug, U. Intergenerational Transmission of Values: The Role of Transmission Belts. J. Cross-Cult. Psychol. 2001, 32, 174-185.

34. Silva, J.M. Constructing Adulthood in an Age of Uncertainty. Am. Sociol. Rev. 2012, 77, 505-522.

35. Phalet, K.; Schönpflug, U. Intergenerational transmission in Turkish immigrant families: Parental collectivism, achievement values and gender differences. J. Comp. Fam. Stud. 2001, 32, 489-504.

36. Celikaksoy, A.; Nielsen, H.S.; Verner, M. Marriage Migration: Just Another Case of Positive Assortative Matching. Rev.Econ. Househ. 2006, 4, 253-275.

37. Okumura, T.; Usui, E. Do Parents' Social Skills Influence Their Children's Sociability? IZA Discussion Paper No. 5324; Institute for the Study of Labor (IZA): Bonn: Germany, 2010.

(C) 2014 by the author; licensee MDPI, Basel, Switzerland. This article is an open access article distributed under the terms and conditions of the Creative Commons Attribution license (http://creativecommons.org/licenses/by/3.0/). 